\title{
Konukseverlik Etiğinin İlişkisel Analizi ve Hakikatler Etiği
}

\author{
DOI: $10.26466 /$ opus.845830 \\ * \\ Baran Yıldırım* \\ * Dr. Öğr., Anadolu Üniversitesi, Sosyoloji Bölümü, Eskişehir/Türkiye \\ E-Posta: baranyildirim83@gmail.com \\ ORCID: $\underline{0000-0001-8087-7512}$
}

\section{Öz}

Bu çalışmada konukseverlik etiğinin ilişkisel analizi, birbiriyle içsel bağlantıları olan iki farklı bağlamda tartışılmıştır. Bu iki farklı bağlam iki farklı düşünsel yöntemle gerçekleştirilmiştir. Ilkin soyutlama yöntemiyle konukseverlik etiğinin belirleyici ilişkileri tarif edilmiştir. Böylece, konukseverlik etiğini metafizik bir bağlamdan çıkartıp sosyal bilimsel analiz birimine nasıl dönüşebileceğine dair bir çerçeve sunulmuştur. İkinci bă̆lamda; konukseverlik etiği ile hakikatler etiğinin hakikat temelli sentezi yapılmıştır. Bu sentez, koşulsuz kabulün reel politik sınırlarını açı̆̆a çıkartması beklenen sorgulamalar aracılığıyla sağlanmıştır. Konukseverlik etiğine dair felsefi sorgulamalarda Derrida'nın çalışmaları temel alınmış, Badiou'nun hakikatler etiğine dair ortaya koyduğu çerçeve üzerinden de eleştirel bir yeniden okuma gerçekleştirilmiştir. Konukseverlik etiğinin eleştirel yeniden inş̧ası, soyutlama yöntemiyle açı̆̆a çıkan ilişkilere bağhl kalarak ilerletilmiştir. Böylece birbirine karşıt duran iki etik felsefenin sentezinin eklektik kalma tehlikesinden kaçınılmıştır. Bu çalışmanın pratik bağlamı güncel mültecilik krizidir. Bu krize cevap olarak düşünebileceğimiz etik felsefenin reel politik içerisindeki sinırlllıları ve olanakları güncel mültecilik krizini de çözüme kavuşturabilecek politik öznenin bağlamına doğru genişletilerek tartışılmiştır.

Anahtar Kelimeler: Etik, Konukseverlik, Mültecilik, Özne. 


\title{
Relational Analysis of Hospitality Ethic and The Ethic of Truths
}

*

\begin{abstract}
In this study, relational analysis of hospitality ethic has been discussed within two different context which have internal connections each other's. Two different contexts have been constructed two different intellectual method. First, determined relations of hospitality ethic has been described within abstraction method. Thus, the frame has been demonstrated how hospitality ethic come into social scientific analysis unit from its metaphysics context. Secondly; hospitality ethic and truth of ethic has been synthesized based on truth. This synthesis has been obtained through investigations which revealing to limitations of real politic of unconditional accept. The debates on philosophy of hospitality ethic which ground on Derrida's studies has been reread with criticism which had been framed by Badiou regarding the truth of ethic. The critical reconstruction of hospitality ethic has been furthered adhere to relations of its which disclosure with abstraction method. Therefore, there've been avoided that the synthesis of two contrary ethic philosophy could have been remained with eclectically. The practical context of this study is current refugee crisis. The limits and possibilities of ethic philosophy in the reel politics which it can comprehend an answer of this crisis has been discussed to extend within the context of political subject which can solve refugee crisis.
\end{abstract}

Keywords: Ethic, Hospitality, Refugee, Subject. 


\section{Giriş}

Son yıllarda gerçekleşen zorunlu göç hareketleri ve bu hareketliliğin yarattığı toplumsal sonuçlar, konukseverlik kavramına yönelik tartışmaları yeniden gündeme getirmektedir. Literatürdeki tartışmalardan yola çıkarak sosyal bilimsel analiz birimine dönüştürülebilecek konukseverlik kavramı; böylelikle, etik ile reel-politik arasındaki ilişkileri de açığa çıartabilecektir. Bu sayede, konukseverlik etiğini politik bir edime dönüştürme ve bu edim aracılığıyla güncel mültecilik sorunsalının çözümünde kavramsal/kuramsal bir öneride bulunma olanakları ortaya çıkabilir.

Literatürde geçen konukseverlik kavramı, merkezi olarak antropoloji ve felsefe disiplinlerine konu olmuştur. Konukseverlik kavramı antropolojik çalışmalarda; 'sosyal bir kontrol arac1', 'büyülü-dinsel' bir motivasyon, 'armağan ekonomisinin' bir parçası ya da 'mübadele' biçimi olarak tarif edilmiştir. (Molz ve Gibson, 2007; Brathertoon ve Wood, 2007; Selwyn, 2000; Telfer, 2000; Baker, 2013; Lynch, 2007)

Bu makalenin kuramsal zeminini oluşturan felsefe disiplinindeki konukseverlik tartışmaları ise Derrida'nın çalışmalarında ayrıntılı bir şekilde ele alınmıştır (1999a, 1999b, 1999c, 2000). Derrida'nın 'konukseverlik etiği'; Levinas'ın (2013) etik felsefesine konukseverlik kavramını eklemlemesi ve Kant'ın 'evrensel konukseverlik hakkı' olarak tarif ettiği konukseverlik hukukuna yönelik yapıbozumcu analizi aracılığıyla oluşmuştur. Derrida'ya göre konukseverlik hukuksal düzlemde ele alındığında, kendine içkin bir açmazı olarak konuksevmezliğe(hostility) dönüşebilmektedir. Koşulsuz/mutlak/saf konukseverlik, gelen misafirin hukuksal sınırlama olmaksızın her koşul altında kabul edilmesini ifade etmektedir. Levinas'ın etik felsefesindeki sonsuz 'Öteki' ve ‘Ben' arasında kurulan ilişki, Derrida'nın konukseverlik etiğindeki misafir-ev sahibi ilişkisinin ilkesel çerçevesini belirlemiştir. Mutlak konukseverlik, misafirin ev sahibinin yerini almaya çalıştığı koşullarda dahi gösterilen konukseverliktir.

Badiou'nun hakikatler etiği ise, konukseverlik etiğinin bu felsefi güzergahının tam karşısında mevzilenmiştir. Ona göre 'sonsuz fark olan şeydir' ve etik olması gerekenle ilgilenmelidir (Badiou, 2016). Bundan dolayı etik; olması gerekene kılavuzluk edecek hakikatin ayrılmaz bir parçasıdır. Hakikatle onun taşıyıcısı özne arasındaki ilişkiyi belirleyen pratikler topla- 
mıdır. Bu pratikler, konukseverlik etiğinin buyruklarının tam tersine, '1srar' edimiyle sürdürülebilir. Bu makalede Badiou'nun etik felsefesine, konukseverlik etiğinin reel politik sınırlarını açığa çıartmak için başvurulmuştur. Aynı zamanda her iki etiğin, kendine içkin pratikleri üzerinden sentezlenmesi ve böylece 'bir hakikatin' sürdürülmesi konusunda daha kapsamlı bir pratik çerçevenin oluşturulması hedeflenmektedir. Bu sentez çabası, konukseverlik etiğinin (mutlak/saf/koşulsuz konukseverliğin) nasıl bir hakikat içerisinde pratiğe dönüşebileceğini tartışmayı zorunlu kılmaktadır. Bu çaba, aynı zamanda, konukseverlik etiğini ilişkisel bir analiz birimine dönüştürebilmenin de cevaplarını bulmaya yarayabilir.

Konukseverlik etiğinin ilişkisel analizi, realist bilim paradigmasının ilkeleri takip edilerek yapılacaktır. Sosyal bilimlerde realist yaklaşım, hakikati ilişkisel olarak kavramamızı ve bu bağlamda analize girişmemizi önermektedir. Bu yaklaşım içerisinde birden çok metot olsa da bu makalede takip edilecek yöntem, Sayer'in 'soyutlama ve yapısal analiz' modeli olacaktır. Bu model bir kavramı ya da bir konuyu, alan araştırmasına önsel olarak düşünsel kategorilerde inşa etmenin en verimli yollarından birisidir. Kavramın ya da konunun belli başlı ilişkilerini ayırt etmek ve bu ilişkilerin mahiyetini tespit etmek üzerine kuruludur. İlişkiler -dışsal/içsel, simetrik/asimetrik ve zorunlu/olumsal- türünden ikiliklerin bir arada ele alınmasıyla ayırt edilmektedir.

$\mathrm{Bu}$ çalışmada, konukseverlik etiğine dair yapılacak soyutlamada ortaya çıkan ilişkiler, düşünsel bir kategorik inşa süreci olarak ele alınmal1dır. Fakat pratikten soyutlanmış bir düşünsel kategorinin oluşamayacağı noktada, konukseverlik etiğine dair bu çalışmada oluşturulan kategorilerin toplumsal yaşama tekabül eden bir yanının olduğu da aşikardır. Bu bağlamda oluşturulan kategoriler sadece 'olması gereken' kişisel bir temenniye değil, aynı zamanda 'olanın' gözlemlenmesini içeren düşünsel bir sürece dayanmaktadır. Buna rağmen; olanın gözlemlenmesi aracıl1ğıyla oluşturulan kategoriler, kesin bir bilimsel iddiaya indirgenmemelidir. Bu çalışmada oluşturulan kategoriler, en fazla, sosyal bilimsel araştırmalarla sınanabilecek kavramsal bir çerçeve olarak görülebilir.

Bu çerçeveyi çizebilmek adına, öncelikle araştırmanın yöntemine (soyutlama) ve bu yöntemin yaslandığı bilim paradigmasına (realizm) değinilmiştir. Akabinde bu yöntemle, konukseverlik etiğinin ilişkileri analiz edilmiştir. Sonrasında her iki etik felsefenin eleştirel analizi yapılmış ve 
iki etik arasında kurulacak sentezin bağlamı tartışılmıştır. Sonuç bölümünde, kuramsal kavramsal çerçeve yeniden inşa edilerek, güncel mültecilik krizine dair nasıl bir perspektif sunabileceği ele alınmıştır.

\section{Yöntem}

Derrida'ya göre konukseverlik; analiz birimi olarak kullanılamaz, temalaştırılamaz veya izlekleştirilemez (Yeğenoğlu, 2016). 'Bir anlık vuku bulabilir' ancak 'bir kural olarak' ele alınamaz.

Bu çerçevede, konukseverlik etiğinin sosyal bilimsel bir izlek haline nasıl dönüştürüleceği sorusu gündeme gelmektedir. Bu çalışmada, soyutlama ve yapısal analiz yöntemi yardımıyla konukseverlik etiği izi sürülebilecek bir tema haline getirilmeye çalışılacaktır. Fakat bu yöntemi ayrıntılarıyla tartışmadan bir adım önce, 'yapısal analizin' kuramsal olarak yaslandığı realist bilim paradigmasına kısaca değinmek gerekir.

Sosyal bilimlerde realist paradigma, birbirine karşıt mevzilenen iki bilim paradigmasına (inşacılık ve doğalcılık) yönelik eleştirel bir kavrayış üzerine bina edilmiştir. Bu eleştiriler, her iki bilim paradigmasının da hakikati eksik tarif etmeleri üzerine yoğunlaşmaktadır. Realizme göre hakikat; ne natüralistlerin tasvir ettiği gibi tamamen onu çalışan özneye dışsaldır ne de inşacıların tersine çevirdiği şekilde sadece onu (hakikati) çalışan öznenin perspektifinden ibarettir. 'Hakikat ilişkiseldir'(Vadanberghe, 2010, s. 385). Başka bir deyişle -düşünce tarihi boyunca çoğu zaman bir birine karşıt olarak betimlenen- özne ve nesne ancak bir arada, aynı zaman ve uzamda bir hakikatin oluşumuna katılırlar.

Hakikatin bu ilişkisel mantığını ayrıntılı bir şekilde ortaya koyan çalı̧̧malar, farklı kavramsal modellere dayansa da aynı noktayı vurgulamışlardır: Özne ve nesnenin (ya da yapı ve failin) hakikatin oluşumuna katkıları bakamından ontolojik bir ayrım gözetilemez ancak katkılarının nitelikleri bakımından analitik bir ayrım yapılabilir'1. 'Gerçek ilişkiseldir ancak gerçek ilişkiler a priori olarak' mutlak kabul edilemezler, 'onlar ancak bilimin indirgenemez süreçleri ile açığa çıartılabilir' (Bhaskar, 2012, s.45). Bir kavramın ya da bir olayın ilişkileri, sistematik bir pratiğin içerisinde

${ }^{1}$ Farklı çalışmalar için bkz: Roy Bhaskar Naturalizmin Olanaklıı̆ı (2012), Gerçekliği Geri Kazanmak (2015), Andrew Sayer Method in Social Science (2010), Emrah Göker ve Güney Çeğin Tözcülügün Tasfiyesi (2010). 
yeniden düşünülmelidir. Realist bilim paradigmasının ayırt edici özelliği olan bu düşünümsellik, düşünülmemiş kategorilerin bilimsel bir pratik içerisinde yeniden inşa edilmesini (ya da gözden geçirilmesini) gerekli k1lar.

Ancak bu durum, bir nesnenin ilişkilerini a priori olarak tasarlayamayacağımızı göstermez. Tam tersi, düşünülmemiş kategorileri düşünmek için öncelikle düşünülmüş kategorilerin sahaya sürülmesi gerekir. Böylelikle önsel oluşturulmuş kategorilerin 'pratik yeterliliğini' anlamak mümkün olabilir.

Sayer'in oluşturduğu yapısal analiz ve soyutlama modeli, a priori kategorileri realist paradigma içerisinde inşa etmenin yollarını göstermektedir. Çünkü bu model, nesneye dair bir takım ilişkileri 'düşüncede ayırt etmeyi' önermektedir (Sayer, 2010, s.28). Bu ilişkiler, içsel ve dışsal, simetrik ve asimetrik, zorunlu ve olumsal ilişkiler olarak tarif edilmektedir.

İçsel bir ilişkide, ilişkinin bir tarafındaki nesne ile diğer taraftakiler bir arada var olurlar ve bir taraf olmadan diğer taraf tarif edilemez. Birindeki niteliksel değişim diğerini doğrudan etkiler. Nesnelerin doğası böyle bir ilişki içinde olmaya bağlıdır. Dışsal bir ilişkide ise nesnelerin doğası böyle bir ilişki içinde olmaya bağlı değildir. Birinde gerçekleşen her hangi bir değişim diğerini etkilemez. Bu durum, yine de dişsal bir ilişkinin önemsiz olduğunu değil, başka bağlamlara sahip olduğunun göstergesidir.

Soyutlanması gereken diğer bir ilişki biçimi simetrik ve asimetrik ilişkilerdir. Simetrik bir ilişkide taraflar ancak birlikte mevcut iken, asimetrik ilişkide; ilişkinin bir tarafı diğeri olmadan da var olabilir. Fakat diğer taraf bu kabiliyete sahip değildir. Yani kendi başına var olamaz.

Üçüncü olarak zorunlu ve olumsal ilişkileri ayırt etmek gerekir. Zorunlu ilişkiler olmazsa olmaz ilişkilerdir. Bir olayın gerçekleşmesi için başka bir olayın daha zorunlu olarak gerçekleşiyor olması gerekir. Olumsal ilişkiler ise olaylar arası bağlantıyı, bir dizi etkileşimler örüntüsüyle açıklayan ilişkilerdir. Yapısal analiz açısından zorunlu ve olumsal ilişkiler arasında da içsel bir ilişki kurulmaktadır. Zorunlu ilişkiler, kaba natüralistlerin iddia ettikleri gibi tarihsel bir zorunluluk olarak tanımlanmamaktadır (Sayer, 2010, s.29). 
Zorunlu ilişkiler ancak olumsallık bağlamında anlaşılabilir. Olumsallık birbirleri için zorunlu olan olayların hangi koşullar altında etkileşime girdiğini ifade etmektedir. Bir olayın gerçekleşmesi için zorunlu olan ilişkiler, her koşul altında, her zaman diliminde ve her mekanda aynı şekilde değişmez ilişkiler değildir. Zorunlu ilişkilerin gerçekleştiği koşullar (olumsallık alanı) bu ilişkinin yapısını belirler. Zorunlu ilişkileri olan farklı öznelerin bir arada bulunuşları sabit bir yasayı gerekli kılmaz.

Soyutlamaya dair zorunlu ve olumsal ilişkiler aynı zamanda 'nedensellik' tartışmasına girilmesini mecbur kılmaktadır. Nedensellik, kaba natüralizm açısından bir düzenlilik, tarihsel (düz çizgisel) süreklilik anlamları taşımaktadır. İndirgemeci bir neden-sonuç ilişkisidir. Realist paradigma için nedensellik ise 'nesnelerin güç ve hassasiyetlerini' sahip oldukları 'doğasına' indirgemek yerine, bu 'güç ve hassasiyetlerin' kendi içsel ilişkilerinde nasıl etkilerde bulunduğunu sınamaktır (Sayer,2010, s. 58). Bir nesnenin kendine içkin, kendi 'doğasında' sahip olduğu varsayılan güçler, esasen onun başka bir nesnenin bir yönünde yaptığı etkide varlık kazınırlar. Çünkü sosyal bilimlerin nesnesinin, yani öznenin, doğası etkileşimsel bir yapıya sahiptir. Nesnelerin bu etkileşimsel boyutu o nesnelerin olumsal ilişkilerini ifade ederken, bu etkileşim içerisinde ortaya çıkan güçler ve hassasiyetler, nesnenin bu bağlamda doğası, zorunlu ilişkileri temsil eder.

$\mathrm{Bu}$ çalışmada konukseverlik etiğinin ilişkileri soyutlama modeliyle ayırt edilmiştir. Soyutlanmanın pratik bağlamı olarak ise güncel mülteci krizi karşısında alınan toplumsal tutumların tasvirleri kullanılmıştır. Mültecilerin gündelik yaşamlarına koşulsuz konukseverliği temsil eden pratiklerle yaklaşan toplumsal grupların temel motivasyonları, konukseverlik etiğinin ilişkilerinin betimlenmesine zemin hazırlamıştır. Koşulsuz konukseverliğin zorunlu ve olumsal ilişkileri böyle bir önsel soyutlamanın ürünleri olmuştur.

Soyutlama modeli, konukseverlik etiği kavramını metafizik atıflar içeren bir bağlamdan sosyal bilimsel bir bağlama dönüştürebilmenin önsel adımı olarak kullanılmıştır. Böylelikle bu çalışmanın ikinci adım analizi olarak, her iki etik felsefeyi (konukseverlik ve hakikatler) sentezleyebilmenin zemini ortaya çıkmıştır. Yapısal analize dair diğer ilişki biçimlerinin (içsel/dışsal ve simetrik asimetrik) bu çalışmanın konusu bağlamında etkileri olmadığı düşünülerek parantezi alınmış ve sadece zorunluluk ve 
olumsallık ilişkileri soyutlamaya dahil edilmiştir. Çünkü konukseverlik etiğinin zorunlu ve olumsal ilişkileri, sürdürülmesi gereken bir hakikat tasavvurunu -ve böylece hakikatler etiğini- gerekli kılmaktadır. Bu iki aşamalı analizin ilk adımı olarak, öncelikle konukseverlik etiğine dair ana eksen literatür tartışmasına girilmesi gerekir.

\section{Literatürde Konukseverlik}

Konukseverlik kavramına dair literatürde geçen tartışmalar iki ana disiplinden beslenmektedir. Antropolojik çalışmalarda konukseverliğin belli kültürel formlar içerisinde kazandıkları anlamlar ve tarihsel seyir içerisinde bu anlamların değişen atıfları tartışılmıştır. Bir kısım araştırmacı konukseverliği, 'yabancıdan' gelecek tehlikeyi dindiren 'sosyal bir kontrol aracı' ya da sosyo-ekonomik bir değişim aracı olarak tanımlamıştır (Brathertoon ve Wood, 2007 ; Selwyn, 2000; Telfer, 2000). Bazı araştırmacılar konukseverliğin, Antik döneme ait bir 'büyülü-dinsel yabancı korkusuna' dayandığını ortaya koymuştur (Baker, 2013; Selwyn, 2000). Konukseverliğin önemli bir motivasyonu olarak, tanrıların misafir kılığında kullarının imanını test ettiğine dair dinsel inanışlar işaret edilmektedir (Selwyn, 2000, s. 32). Bir kısım araştırmacı ise kavramın etimolojik kökenine odaklanan tarihsel yaklaşımı esas almışlardır. Konukseverliğin Orta çağ İngilizcesi, Grek ve Latin kökenli yörüngesinden giden araştırmacılar, kavramin; kurban, güç, zorunluluk, karşılıklılık ve koruma gibi anlamlarını ön plana çıkartmışlardır (Lynch, 2007; O'Gorman, 2007). Buradan hareketle konukseverlik; kavramın etimolojik kökenine gömülü konukseverliğin (hospitality) ve düşmanlığın (hostility) diyalektiği yoluyla ulaşılan kültürel bir form olarak görülmektedir (Lynch, 2000, s.17).

Konukseverlik kavramını felsefe içerisinde tartışmaya açan Derrida, benzer şekilde kavramın etimolojik kökenindeki karşıtlığını ele almış, yapı bozum stratejisiyle konukseverliği bir hukuk formu yerine etik bir çerçeveye dönüştürmüştür (Derrida, 2000). Konukseverlik kavramının felsefi çerçevede ortaya çıkan tartışmaları, bu çalışmanın kuramsal zeminlerinden birini oluşturmaktadır. Bundan dolayı, çalışmanın kalan kısminda antropolojik araştırmalara atıflar olsa da ana eksen tartışma olarak konukseverliğin felsefe içerisindeki anlamı ayrıntılı olarak tartışılmıştır. 
'Konuksev (er/-mez)lik' Hostipitalité (1999b) adlı çalışmasında Derrida; ev sahibi (host) ve düşmanlık (hostility) arasındaki etimolojik ilişkinin, konuğu kaçınılmaz biçimde öteki olarak tanımlayan konukseverlik fikrini perçinlediğini ileri sürer (Stocker, 2006, s.337). Sınırları çizilmiş bir 'ev' ve bu evin sahibini -sahipliğin getirdiği otoriteyi- var etmeyen bir konukseverlik hukuku mümkün değildir, Derrida'ya göre:

“Konuksever; konukseverliğin, ağırlamanın koşullarını evin patronunun, kabul edenin, kendi evinde, kendi devletinde, kendi ulusunda, kendi kentinde efendi olanın, kendi evinde efendi olarak kalanın tanımladığ yerde; dolayısıyla koşulsuz ağırlamanın, kapıyı koşulsuz olarak geçmenin olmadığ 1 yerde yapar... Konukluk elbette bir hak, bir ödev, bir zorundalık, bir yasadır, yabancı ötekinin bir dost olarak ağırlanmasıdır, öyle olması gerekir; ancak bunun koşulu ev sahibinin, host'un, Wirt'in, kabul eden ya da barındıran ya da iltica hakkı verenin, evin efendisi olarak kalması, kendi evinde kendi otoritesini koruması, dolayısıla konukluk yasasını evin, kendi evinin yasası, yerin (ev, otel, hastane, yurt, aile, kent, ulus, dil) yasası olarak, sunulan konukseverliğin kendisinin yerinin sınırlarını çizen ve onun üzerinde otoritesini koruyan, otoritenin doğruluğunu koruyan, korumanın yani doğruluğun yeri olarak kalan ve dolayısıyla sunulan armağanı sinırlayan ve bu sinırlamayı, yani kendi evinde kendi olmayı, ödülün ve konukseverliğin koşulu yapan özdeşlik yasası olarak olumlamasıdır" (Derrida, 1999b, s.47-48).

Derrida, konukseverliğin bir hak olarak tanımlanması durumunda bu hakkın hangi koşullarda kullanılabileceğini işaret etmektedir. Ev sahibi otoritesinin yeniden üretimini sağlayan koşullar olmaksızın, konuk olma hakkının kullanılamayacağı aşikardır. Derrida bu çalışmasını, Kant'ın ebedi barış önerilerinden biri olan konukluk hakkına dair eleştirileriyle ele almıştır.

Kant, Ebedi Barış Üzerine Felsefi Bir Deneme'de (1960) insanlığın barış altında yaşayabilmesi için zorunlu olarak gördüğü hukuksal çerçeveyi çizmiştir. Evrensel konukseverlik hukuku Kant açısından, insanlığın barış içerisinde yaşamasının ön şartlarından biridir. Klasik sömürgeciliğin yoğun bir şekilde yaşandığ tarihsel döneme denk gelen ebedi barış denemesi; dostane komşuluk ilişkisini içeren 'yeni bir hukuku', 'başka ulusların iç işlerine karışmamayı, vatandaşları kendi devletlerine karşı kışkırtmamayı, silahsızlanma, düzenli orduları aşamalı olarak kaldırma' gibi 
önerileri içerir (Kant, 1960, s.9-15). Konukseverliğin normatif bir hukuk meselesi olduğu açıkça vurgulanır ve bu hukukun korunması belli şartlara bağlanır;

"Bu maddede de, bundan önceki maddelerde olduğu gibi, insanseverlik değil hukuk bahis konudur. Misafirlikten kast edilen her yabancının geldiği memlekette düşmanca muamele görmeme hakkıdır. Yabancının hayatın tehlikeye sokamamak kaydıyla, kendisinin ülkeye girmemesi istenebilir; ama huzuru bozmadıkça ona karşı düşmanca davranılmaz" (Kant,1960, s.26).

$\mathrm{Bu}$ alıntıdan açıkça anlaşılacağı gibi Kant açısından konukseverlik, doğrudan misafirlik olgusu üzerinden ilişkilendirilerek analiz edilir. Misafir olabilmenin belirlenmiş koşulları vardır ve konukseverlik ancak bu koşulların yerine getirilmesi ile sağlanabilir. Gelen 'misafirin' geldiği 'evde' yaşayanların huzurunu bozmama koşuluyla konukseverlik görebileceği belirtilmiştir. Güncel mültecilik krizine dair düşündügümüzde, 'huzuru bozmama', kamusal politikalarda ve merkezi toplumsal tutumlarda ortaya çıkan konuksevmez perspektifin en temel argümanlarından biri olarak görülebilir. Derrida'nın konukseverliği ‘bir hak olarak' ele almaya iki yüz yıl sonra yaptığı itiraz da bu reel bağlama denk gelmektedir. Konuk olmanin yasaları, ev sahibinin -otoritesinin- yasaları olmak zorundadır. Bu yüzden Derrida konukseverliği bir yasa olarak ele almak yerine, bir etik pratik olarak ve hatta etiğin kendisi olarak ele almıştır.

'Özdeşlik yasası olarak' koşullu konukseverlik; ötekinin 'biricik' olarak kabul edilmediği, koşulların aracılığıyla 'ben' olan özneye indirgendiği ya da benin tahakkümüne indirgendiği- bir özdeşleşme durumu yaratmaktadır. Derrida, konukseverlik hukukuna yönelik yapı bozumcu bu operasyonu, Levinas' ın; ben-öteki ilişkisi bağlamında özdeşleş(tir)me felsefesine yönelik eleştirel yaklaşımlarını esas alarak inşa etmiştir (Derrida, 1999c). Ötekini sorgusuz sualsiz ve elbette koşulsuz karşılamak konukseverlik etiğinin temelidir.

“Saf bir karşılama yalnızca Öteki'nin kimliği, arzusu, kuralları, dili, çalışma kapasitesi, bütünleşme kapasitesi, uyum gösterme kapasitesi hakkında hiçbir şey bilmemeyi veya hiçbir şey bilmezmiş gibi yapmayı değil, aynı zamanda bu konudaki tüm soruları savuşturmayı gerektirir" (Derrida 1999 c, s. 28). 
'Bir kapı veya penceresi olmayan hiçbir ev veya iç yoktur'(Derrida, 2010, s.61). Yani sınırları olmayan, geçiş eşiği bulunmayan bir mekanın olması mümkün değildir. $\mathrm{O}$ zaman bu gerçek koşulsuz konukseverliğin de mümkün olmadığını söylemektedir. Derrida felsefesinde etik; ben ve ötekinin ilişkisinde, ötekini koşulsuz kabul etmek olarak ele alındığı noktada olanaksız olarak görülmektedir (Gültekin, 2014, s.21).

Derrida, ben ve ötekinin kesintili, döngüsel ve yer değiştirme ilişkisini, koşulsuz konukseverlik kavramının soyut çıkarımında şu şekilde yorumlamıştır:

“Karşılayan (ev sahibi), karşılananı (misafir) veya davet edileni karşılayan kişi, kendini evin sahibi kabul ederek (hoş) karşılayan kişi, gerçekte kendi evinde karşılanan bir misafirdir. Kendi evinde sunduğu konukseverliği, son kertede kendine ait olmayan evinde gören kişidir. Ev sahibi olarak karşılayan kişi misafirdir" (Derrida, 2010, s.65).

Ev sahibi ve misafir özneler arasındaki bu döngüsellik, zorunlu olarak bir takım dolayımları düşünmeyi gerektirir. Bu dolayımların en temelinde özel mülkiyet rejiminin olduğunu varsayabiliriz. Ev sahibi ve misafir arasında hiçbir geçirgenliğin olamayacağı koşullu konukseverlik, özel mülkiyet rejiminin sürekliliği içerisinde cereyan etmektedir. Bu rejim, evin özel mülkiyetini elinde bulunduran kişi ile evin otoritesine sahip olanı özdeşleştiren bir kavrayışın ürünüdür. Evin sınırları içerisindeki en yüksek otorite, eve -yasal ya da kullanım hakkı açısından- sahip olan öznedir ve eve sahip olmaktan kaynaklı otoritesinin bozulmadığı koşullarda konukseverlik göstermektedir. Özel mülkiyet rejiminin ortaya çıkardığı otorite ilişkileri, ev sahibi misafir ilişkisinin mecaz olmayan bağlamında açıkça sezilebilir. Misafir olarak ev içi karar alma süreçlerinde sürekli olarak ev sahibinin iznine başvuran iletişimlerimiz, (koşullu) konukseverliğin özel mülkiyet rejimi içinde gerçekleştiğinin göstergelerinden biridir. Bu durum koşullu konukseverlik içerisinde misafirin de özel mülkiyet rejimini önsel olarak onayladığı anlamına gelmektedir. Konukseverliği kabul eden misafir, ev sahibinin otoritesini de kabullenmiş bulunmaktadır. Özel mülkiyet rejimi koşullu konukseverlik içerisinde, hem misafirin hem de ev sahibinin önsel olarak onayladığı bir ilişki biçimidir.

Ev sahibi misafir arasındaki bu dolayımı genişletilmiş bir mecaz olarak kullanarak, güncel mültecilik meselesinde devletlerin ve toplumların konukseverlik siyasetleri bağlamında da ele alabiliriz. Bu bağlamda özel 
mülkiyet rejimi başka bir takım dolayımlarla beraber çalışmaktadır. Ancak mantık aynen devam etmektedir. 'Evin sahibinin' otoritesi sarsılmadıkça ya da ev ahalisinin 'huzuru bozulmadıkça' konukseverlik gösterilmeye devam eder. Burada özel mülkiyet rejimiyle beraber çalışan özgün bir dolayım olarak ulus devlet rejimleri dikkate alınmalıdır. Ulus devlet rejiminin yurttaşlık hukukuna bağlı yapılaşma mantığı, evin içi ve dışı arasında somut sınırları inşa ederken, ev içindeki somut sınırları da muğlaklaştıran bir işleve sahiptir. Yurttaşlık, ulus devlete egemen olan toplumsal sınıflar ile ezilen sınıfların ortak bir çıkara sahip olduğuna dair illüzyonun modern toplumlardaki en belirgin temasıdır. Öyle ki bu temanın en net taşıyıcısı milliyetçilik ideolojisi, 'ev ahalisi' ile 'evin gerçek sahiplerinin' aynı gemide oldukları inancını kurumsallaştırmaktadır. Bu durumda siyasal anlamda (koşullu) konukseverlik, hem dişarıdan gelen misafirin (güncel olarak mültecilerin) kontrol altına alınmasını hem de ev içi 'aynı gemi' illüzyonunu devam ettiren milliyetçilik ideolojisinin yeniden üretimini ifade etmektedir.

Koşullu konukseverliğin bu dolayımlarına yönelik (konuksever) öznenin 'vazgeçme' edimine dayalı verdiği karar, koşulsuz konukseverliğin pratik zeminini ortaya çıkartmaktadır. Ev sahibi iken misafir olabilen öznenin, eve sahip olma hakkından ve bu hakkın ona tanıdığı otoriteden vazgeçmiş olması gerekir. Özel mülkiyet rejimine karşıt bir kavrayışı olmayan özneden bu tarz bir vazgeçme eylemi beklenemez. Aynı şekilde ulus devlet rejimine -ve bu rejimin sürekliliğini sağlayan ideolojik, hukuki ve politik bağlamlara- karşıt bir kavrayışın, konuksever öznenin pratiklerine rehber olması gerekir. Yaşadığı coğrafyanın ve o coğrafyadan kaynaklı sahip olunan kimliğin ona sağladığı ayrıcalıklardan vazgeçebilen özne, koşulsuz konukseverlik pratiklerine dahil olabilir. Konukseverlik etiği (koşulsuz konukseverlik), yukarıda saydığımız dolayımlara yönelik öznel bir müdahalenin ('vazgeçme' ve ardından 'ırar') etkileşiminde vuku bulabilir².

\footnotetext{
${ }^{2}$ Ancak buna rağmen; konuksever öznenin, hem özel mülkiyet rejimine hem de ulus devlet rejimine karşıt pratiklerinin gerçekleştiği zaman ve mekanda dahi koşulsuz konukseverlik vuku bulmayabilir. Konukseverlik (koşullu ya da koşulsuz) iki farklı öznenin giriştiği bir iliş̧i biçimidir. Bu yüzden 'ev sahibi' öznenin vazgeçmeye dayalı pratiği koşulsuz konukseverlik ilişkisinin ilk adımı olsa da 'misafir' öznenin misafir olarak kalma kararı, koşulsuz konukseverliğin gerçekleşmesine yönelik ikincil pratiği sekteye uğratmaktadır. Misafir olarak gelen 'ötekinin' içsel misafirlik algısı -bulunduğu mekana yönelik geçicilik algısı- koşulsuz konukseverlik pratikleriyle karşılaşmalarda dahi misafirliği sürdüren bir özne konumunu üretmektedir. İ̧sel
} 
Bu çerçevede konukseverlik etiği; özel mülkiyet ve ulus devlet rejimlerine karşıt hem 'ev sahibi' öznenin hem de misafir 'öznenin' ortaklaştığ1 bir hakikat zemininde gerçekleşmektedir. Bundan dolayı konukseverlik etiğinin yapısal analizi (zorunluluk ve olumsallık ilişkileri), öznenin bu karşıt hakikat zeminine yönelik pratikleri bağlamında yapılabilir. Böylece konukseverlik etiğinin muhakkak bir hakikat tasavvuruyla ve bu hakikati taşıyan öznelerin tutumlarıyla kavranabileceğini belirtmek gerekir.

\section{Konukseverlik Etiğinin Zorunlu ve Olumsal İlişkileri: Özne ve Hakikat}

Derrida'ya göre konukseverlik etiği 'düzenlenebilir' ya da 'denetlenebilir' bir mefhum değildir. Bundan dolayı, Derrida'nın felsefesi içerisinde kalarak sosyal bilimsel bir izlek haline dönüştürülmesi de mümkün değildir:

"Koşulsuz konukseverlik bir kural olarak imkansızdır; onu düzenli bir şekilde organize edemem ve işte bu yüzden, kural olarak, vicdan azabı duyarım; vicdanım rahat olmaz çünkü kapımı kilitlediğimi ve evimi, dairemi, ulusumu, paramı, toprağımı, vs. paylaşmak isteyen insanlar bulunduğunu bilirim. Kural olarak değil diyorum ama bazen, istisnai durumlarda, bu vuku bulabilir. Bu anlarn ne düzenleyebilir, ne denetleyebilir ne de belirleyebilirim ama bu vuku bulabilir; yalnizca bir bağıışlama eylemi olarak, bir bă̆̆ışlama vuku bulabilir; saf bağıışlama vuku bulabilir. Kesin, belirleyici bir yargıda bulunup 'bu saf bağışlayıcılık' veya 'bu saf konukseverlik diyemem; bir ilgi eylemi olarak, belirleyici yargzya uygun bir eylem yoktur...Koşulsuz konukseverlik bir kurum olamaz ama bir mucize olarak vuku bulabilir... bir anda, en fazla bir anlık bir sürede vuku bulabilir. Bu... imkansiz bir şeyin olası vuku buluşudur ve bize konukseverliğin ya da bă̆ışlayıcılığın ya da armağanin ne olabileceğini düşündürür" (Derrida, 2000, s.34).

\footnotetext{
misafirlik algısı, koşulsuz konukseverliğin bir ilişki biçimi olarak gerçekleşmesi önündeki başka bir öznel engel olarak okunmalıdır. Fakat bu çalışmada özneler arası etkileşimden çok, öznelerin dahil olduğu hakikat biçimlerini ve etik felsefelerin yaslandığı hakikat/hakikatsizlik alanlarını -analitik olaraköncelediğimizden dolayı misafir öznenin eylemliliğini ifade eden içsel misafirlik algısını paranteze almayı tercih ettik. Konukseverlik bağlamında özneler arası etkileşimin dahil edileceği analizlerde, misafir öznenin içsel misafirlik algısının derinlemesine tartışılması gerekliliğini not etmek gerekir.
} 
Derrida'nın bu yaklaşımına rağmen, yukarıda değinildiği gibi, konukseverlik ilişkilerine dahil olan öznelerin hakikat konumlanmaları üzerinden konukseverlik etiğinin ilişkisel haritası çıkarılabilir ve sosyal bilimsel bir izleğe dönüştürülebilir. Konukseverlik etiğini bir hakikate atıfta bulunarak analiz etmek, onu 'mucizevi' bir olgudan gerçek ilişkilere dayalı bir olaya çevirebilmenin genel çerçevesini oluşturacaktır. Bunun için, özne ve hakikat ilişkisini etik felsefe içerisinde ele alan Badiou'nun fikirlerine başvurmak işlevsel olacaktır.

Badiou felsefesinde hakikat, olay ve olaya sadık kalan özneler arasındaki ilişkisel süreçle beraber kavranması gerekir. Olay ise, bir durumun adlandırılmamış boşluğunu dolduran eklentidir (Badiou, 2016, s.51). Durum statükoyu, o zamana kadar sorgulanmadan süregeleni işaret etmektedir. “Örneğin fiziğin Einstein'ın 1905 kuramsal önermelerine kadar olan bilindik yasaları durumu ifade eder. Einstein bu önermelerle bir olay, fizik yasaları içerisinde adlandırılmamış ya da tanımlanamamış bir eklenti sunar. $\mathrm{Bu}$ önermelere sadıksam, klasik çerçevesi içinde kalarak fizik yapmaya devam edemem" (Badiou, 2016, s.52).

Badiou felsefesinde olay, bu bağlamda bir karşıt hakikat temsili gibi kavranabilir. Öznenin olaya sadakat çerçevesinde bir hakikati sürdürmesi, etik felsefenin pratik karşılığı olarak istihdam edilmiştir. Bu çerçeveyi konukseverlik ilişkileri bağlamında ele aldığımızda; özel mülkiyet ve ulus devlet rejimlerinin sürekliliği durumu (koşullu konukseverlik), bu rejimler karşıtı kavrayış ve pratiklerin ise karşıt bir hakikat olarak olayı (koşulsuz konukseverlik) temsil ettiğini düşünebiliriz. Böylece koşulsuz konukseverlik, metafizik bağlamının aksine, konukseverliği gösteren özne açısından bir hakikati sürdürmenin pratik sonuçlarından biri olarak karşımıza çıkar. Bu soyut çıkarımı, güncel mültecilik krizi karşısında sınırları aşan dayanışma ağları örerek konukseverlik pratikleri sergileyen toplumsal grupların politik motivasyonlarına bakarak yapabiliriz. Mültecileri d1şarıdan gelen yabancı tehlikesi olarak görmek yerine, yeryüzünün ortakları olarak gören ve 'ev sahibi-misafir' ikiliğini ortadan kaldırmaya yönelik pratikler ören toplumsal grupların politik konumlanmaları, özel mülkiyet ve ulus devlet rejim karşısında inşa edilmiş hakikatler içerisinde belirginleşmiştir. Bu toplumsal öznelerin güncel mültecilik krizinden bağımsız olarak sadık kaldıkları hakikat, mültecilere yönelik koşulsuz konuksever pratiklerin sergilenmesinin zeminini oluşturmaktadır. Bu karşıt 
hakikat içerisinde belirginleşmiş bilinç profili, konukseverlik etiğinin(koşulsuz konukseverliğin) olumsallık alanı olarak istihdam edilebilir.

Bu bağlamda koşulsuz kabul etmenin olumsal alanı olarak, karşılayan öznenin özel mülkiyetin anlamına dair eleştirel bir kavrayışı olması beklenir. Bir şeye sahip olmanın, toplumsal yaşamda - başka birisinin o şeye sahip olamaması yüzünden- yarattığı en temel eşitsizlik örüntülerini fark etmiştir. Hangi ideolojiden geldiği fark etmeksizin, doğrudan özel mülkiyet rejimine yönelik alternatif bir bilinç sahibidir. Böyle bir bilinç, bir şeye sahip olmanın aslında bir esaret olduğu gerekçesiyle, özel mülkiyetin anlamını olumsuzlar. Bundan dolayı gelen 'misafirin', evin sahibi konumuna dönüşebilme ihtimali karşılayan öznede herhangi bir kaygı yaratmaz.

Bir diğer somut koşut olarak; koşulsuz kabul eden kişinin var olan s1nırlara dair ulus-devlet, ırk, etnisite vb. gibi kavramlar üzerinden eleştirel bir kavrayış geliştirmiş olması beklenir. Bu kavramların tarih içerisinde sonradan inşa edilmiş olduğunu düşünerek, her türlü milliyetçilik akımıyla arasında hem düşünsel hem söylemsel net bir ayrım koymuştur.

Bu noktada belirtmek gerekir ki; konukseverlik etiğinin olumsal alanı olarak ele alınacak bilinç profilini verili bir kesinlik, tamamlanmış bir son nokta ve konukseverlik öncesi istihdam edilecek mutlak bir uğrak olarak düşünmemek gerekir. Aksi durumda bilinci soyut kurucu bir unsur mertebesinde kavrayan idealizme saplanma tehlikesi belirebilir. İlişkisel bir bakış açısı, bilinç ile varlık arasındaki sonsuz diyalektik ilişkiyi anlatan kavramlara ihtiyaç duymaktadır.

E.P. Thompson'ın deneyim kavramı(Thompson, 2004), konukseverlik etiği ile onun olumsal ilişkileri(konukseverlik bilinci) arasında diyalektik bir bağ kurabilir. Konukseverlik deneyimi; konukseverin, karşılama/ağırlama ya da kabul etme deneyimleri aracılığıyla oluşan konukseverlik bi-

\footnotetext{
${ }^{3}$ Deneyim kavramı Edward P. Thompson'ın 'sınıf deneyimi' kavramından yola çıkarak kullanılmıştır. Thompson Ingiliz Iş̧̧i Sınıfının Oluşumu (2004) adlı çalışmasında; bilinç-varlık karşıtı̆̆ının en çok etkilediği tartılmalardan sınıf meselesine, 'sınıf deneyimi' kavramıyla ilişkisel bir çözüm getirmiş; -sınıf-bilincin, işçi sınıfının gündelik yaşam deneyimleri içerisinde oluştuğunu göstermiştir: "Sınıftan, ilişkisiz ve birbirlerine benzemez gibi görünen bir dizi olayı, hem deneyimin ham maddesinde hem de bilinçte birleştirilebilen bir fenomeni anlıyorum. Bunun tarihsel bir fenomen olduğunun altını çiziyorum. Sınıfı bir yapı hatta bir kategori olarak görmüyorum. Insan ilişkilerinde gerçekten var olan (ve oluşumu gösterilebilen) bir şey olarak görüyorum... deneyim kesin görünse de sınıf bilinci görünmez." (Thompson, 2004,s.40).
} 
lincini ve akabinde yine bu bilinç aracılığıyla gerçekleşebilen konukseverlik pratiklerini birbiriyle bağlayan bir mahiyete sahiptir. Konukseverlik deneyimi kavramı aynı zamanda; konukseverlerin kendi arasındaki ve konuksever-konuk arasındaki etkileşimlere, konukseverlik etiğinin olanakları açısından belli bir önem atfeder. Konukseverlik pratiklerine dahil olan öznelerin, kesin bir önsel bilinçle bu pratiklere girmesi gerekliliğini ortadan kaldırır. Güncel olarak koşulsuz konukseverlik pratikleri sergileyen öznelerin kesin bir bilinç profiliyle bu pratiklere dahil olmadığ 1 aşikardır. Kesin olan konukseverlik deneyimleridir ve bu deneyimlerin aracllı̆̆1 ancak konukseverlik bilincini oluşturabilir. Konukseverlik etiğinin olumsal ilişkisi (konukseverlik bilinci) bu bağlamda konukseverlik sergileyen öznelerin deneyimleriyle tarif edilebilir.

Koşulsuz konukseverliğin olumsal alanı ile içsel ilişkisel olan zorunluluk alanını da Badiou'nun özne teorisine dayanarak istihdam etmek mümkündür. Badiou; kaygl, cesaret, üstben ve adalet'i öznenin inşasına etki eden dört soyut ilke olarak kavramlaştırmıştır. Bu dört soyut ilkenin istikrarsız, heterojen ve düz çizgisel olmayan etkileşimi, öznenin inşasına katkıda bulunur. Badiou'ya göre, kaygının cesarete dönüşümü 'özneleşmeyi' ortaya çıkarır (Badiou, 2009, s.328).

Kaygıdan cesarete geçiş; dünyayı var olduğu gibi kabul eden nihilizme karşı bir hareket olarak karşımıza çıar ve esas vurgulanması gereken, bu geçişin bir 'inanç' sistemini -bir ideolojiyi zorunlu kılmamasıdır. Badiou bu noktada Avrupa komünist partilerini örnek gösterir; 'siyaseti mümkün olanın sanatı' olarak kabul eden bu 'sol' siyasetin, aslında kapitalizmi, dünyanın var olan siyasetini olduğu gibi kabul eden nihilist potansiyellerini ortaya koyar (Badiou, 2009, ss.318-19).

Bu çerçeveden bakıldığında kaygıyı cesarete çevirecek olanın; bir düşünce, soyut ilkeler, keskin 'inançlar' veyahut güçlü söylemleri olan ideolojiler olmadığını; bir fiilin, somut bir pratiğin ve belki de bazen hiçbir inanç sistemi ile bağı olmaksızın sadece kendine içkin anlamı ile bir pratik olduğunu söyleyebiliriz. Ötekinin beni yok etme tehlikesine, konuk olarak mültecinin 'kendi evimde beni rehin alma' potansiyeline rağmen konukseverlik pratiği, en ideal formunda ötekini koşulsuz kabul etmek; kaygı ile yüzleşmeyi, 'kaygıdan cesarete' geçişi sağlayacak bir fiili gerektirir. 
Konukseverlik etiğinin zorunluluk alanı olarak tanımlayacağımız bu fiilin neye benzediğini, yine konukseverlik pratiklerine dahil olan toplumsal öznelerin genel motivasyonlarına dair soyut çıarımlardan yapabiliriz. Bugün dünyanın uzak coğrafyalarından gelerek, mültecilerin gündelik yaşamlarına yönelik dayanışma faaliyetlerine katılan gönüllülerin homojen olmayan toplumsal konumlanmalara sahip olduğunu biliyoruz. Konukseverlik pratiklerine dahil olan bu özneler arası farklılık sınıfsal, kültürel, ulusal vb. olabildiği gibi - bu etkenlere bağlı olarak- ideolojik-politik de olabilir. Örneğin özel mülkiyet rejim karşıtı bir kavrayışa sahip olmayan Kuzey Avrupalı orta sınıf bir emekçi, yıllık iznini Türkiye'de bir mülteci dayanışma örgütünde gönüllülük yaparak geçirebilmektedir. Bu tarz bir gönüllüyü harekete geçiren fiilin, koşulsuz konukseverliğin zorunluluk alanı olarak, kaygıyı cesarete dönüştüren fiille aynı olduğunun altını çizmek gerekir.

Bilmediği bir coğrafyaya gelip kendisine bütünüyle 'yabancı' insanlara yönelik dayanışma faaliyeti yürüten öznelerin, diğer tüm politik-ideolojik motivasyonlardan arındırıldığında, bütünüyle yabancı olarak mültecilere yönelik zedelenmiş adalet duygusuyla hareket ettikleri aşikardır. Koşulsuz konukseverliğin zorunluluk alanı, kaygıyı cesarete çeviren fiil, öznenin zedelenmiş bu adalet duygusuna dair aldığ 1 etik sorumluluk olarak karşımıza çıkmaktadır. Bu sorumluluk kararının, kesin bir bilinç profiliyle -bir karşıt hakikati sürdürme motivasyonuyla- verilmeyebileceğinin altını bir kez daha çizelim. Ancak koşulsuz konukseverliğin sadece -zorunlu ilişkisi olarak- mültecilere yönelik zedelenmiş adalet duygusuyla girişilen cesaret pratiğiyle vuku bulamayacağını da akılda tutmak gerekir. Konukseverlik etiğinin olumsal alanı olarak karşıt bir hakikati sürdürme mantığ1 olmaksızın koşulsuz konukseverlik pratikleri ortaya çıkamayacaktır.

Bu soyutlamayı da güncel mültecilik krizi karşısında sergilenen konukseverlik pratiklerinin analitik ayrımı üzerinden yapmak mümkün. Mültecilerin gündelik yaşamlarına yönelik sergilenen yardım faaliyetleri ile dayanışma faaliyetleri arasındaki ayrım, bu soyutlamaya kuramsal dayanak sunmaktadır. Yardım faaliyeti, kendine içkin eşitsiz ilişkisinde, alan el ile veren el arasındaki eşitsiz konumlanmayı yeniden üreten bir pratik olarak sergilenmektedir. Mecazi temsilinde, ev sahibi ile misafir arasındaki mesafeyi yerleşik hale getiren bir koşullu konukseverlik pratiğidir. Özel mülkiyet ve ulus devlet rejimleri karşıtı bir hakikati sürdürme 
motivasyonu olmaksızın, dahil olunan bir konukseverlik pratiğidir. Konuksever öznenin, mültecilere yönelik zedelenmiş adalet duygusunun ortaya çıkardığı cesaret fiilinin tek başına işe koyulduğu bir faaliyet olarak karşımıza çıkmaktadır.

Bunun karşısında, bugün mültecileri dayanışma faaliyetleriyle bulundukları mekanın ortağı haline getirmeye çalışan konukseverlik pratikleri ise ev sahibi misafir ikiliğini ortadan kaldıran bir anlama sahiptir. Konukseverlik etiğinin olumsallık alanı olarak karşıt bir hakikati sürdürme motivasyonu; mültecileri -yardım faaliyetiyle güçlendirilmeye çalışılan- d1şarıdan gelen ötekiler olarak değil, dayanışma faaliyetiyle bu karşıt hakikate ortak edilmeye çalışılan özneler olarak ele almayı gerektirmektedir. 'Ev sahibi' otoritesini ret eden bu konukseverlik anlayış, mültecileri dayanışma faaliyetlerinin ortak öznelerine dönüştürmektedir. Yaşamın her alanının beraberce inşa edilebileceğini gösteren bu türden dayanışma faaliyetleri, mültecileri -içeriye- tabi ötekiler olarak gören koşullu konukseverliği temsil eden yardım faaliyetlerine tamamen eleştirel bir zeminde gerçekleşmektedir.

Yardım faaliyetleri, faaliyeti örgütleyen öznenin bilinç profilinden bağımsız, kendine içkin bir otorite mekanizmasına sahiptir. Dayanışma faaliyeti ise bunun tersine, özneler arasındaki işbölümünü otorite dolayımı üzerinden gerçekleştirmeyen bir mantığa sahiptir. Yardım faaliyetine gömülü alan el-veren el ilişkisi, mültecilere yönelik konuksevmezlik söylemini üretebilme potansiyeline sahipken, yardım yerine dayanışmayı ilke edinen konukseverlik pratiklerinde ise mültecilerle 'öteki' imgesinde bir ilişki kurmak yerine, aynı mücadelenin ortak bir öznesi olarak ilişki kurulmaktadır. Öznelerin politik-ideolojik aidiyetlerinden bağımsız olarak, yardım faaliyetinin başlı başına eşitsiz konumlar üzerinden gerçekleştiğini ve bu eşitsizliği yeniden ürettiğini vurgulamak gerekir. Yardım faaliyetine girişen bir camii derneği imamıla, benzer faaliyetler yürüten seküler liberal bir derneğin gönüllüsünün aynı konuksevmez söylemi paylaşmasının kaynağı bu eşitsiz ilişkinin doğasından gelmektedir.

Dayanışma faaliyetine katılan konuksever özne açısından, bu faaliyete katılmadan önce sahip olduğu konukseverlik bilinci mültecilere yönelik türdeşlik algısını içermeyebilir. Yani yardım faaliyetlerine katılan konuksever özneden çok farklı bir konukseverlik bilincine sahip olmayabilir. 
Ancak dayanışma faaliyetinin kendine içkin özneler arası denklik mantığında, mültecilerle kendisi arasında bir farklılık olmadığını deneyimleyecektir. Bu bağlamda konukseverlik deneyiminin, konukseverlik etiğinin olumsallık alanı olarak karşıt bir hakikate dayalı bilinç profilinin inşasına giden kesin bir pratik olduğunu görebiliriz. Konukseverlik deneyiminin bir adım gerisinde ise özneleşmenin (bu bağlamda konuksever özneleşmenin) ilk adımı olarak kaygıyı cesarete çeviren fiile ihtiyaç olduğunu belirttik.

Bu soyutlamanın akabinde ortaya çıkan konukseverlik etiğine dair ilişkisel haritayı şu şekilde özetleyebiliriz: Koşulsuz konukseverlik konuksever öznenin, mültecilere yönelik zedelenmiş adalet duygusunun harekete geçirdiği cesurca bir fiili (zorunluluk alanı), karşıt bir hakikat olayına sadakat (olumsallık alanı) çerçevesinde hayata geçirmesi akabinde vuku bulabilir. Konukseverlik deneyimi ise, konukseverlik etiğinin zorunluluk ve olumsallık alanları arasındaki ilişkiyi sağlayan dolayımsız bir pratik olarak istihdam edilmelidir. Bu ilişkisel harita aynı zamanda konukseverlik etiğini hakikatler etiği ile sentezlemenin kuramsal çerçevesini oluşturmaktadır.

\section{Aynı: Politik Özneye Dönüş}

Bu bölümde Badiou'nun etik felsefesi daha yakından analiz edilecek ve konukseverlik etiğini hakikat temelli yeniden inşa etmenin kuramsal/kavramsal çerçevesine dair çıkarımlar yapılacaktır.

Badiou'ya göre; konukseverlik etiğinin ben/öteki arasına koyduğu sonsuzluk ve bu sonsuzluk kavrayışının oluşturduğu etik, 'var olanı tanımak' dışında yeni hiçbir şey söylememektedir. 'Sonsuz başkalık zaten olan şeydir. Her türlü deneyim sonsuz farklılıkların sonsuz açılımıdır. Görünüşte düşünümsel olan kendilik deneyimim bile, hiçbir şekilde bir birlik sezgisi değil, bir farklılaşmalar labirentidir' (Badiou, 2016, s.39). 'Öteki' ile kendim aramda bir özdeşlik kurmamak, Aynı'nın alanına dair bir ortaklaşma inşa etmemek, 'öteki' ile beraber yaşamanın politik ve toplumsal araçlarını görmezden gelen nihilist bir var oluşa kapı aralar gözükmektedir. Badiou'nun meramı açıktır; toplumsal hakikati, felsefi anlamda ontolojiyi, 
hükümsüz kılan 'farklılıklar etiği' tartışmalarına karşı hakikat savunuculuğu yapabilecek bir etik alan inşa etmek. Böyle bir etik ancak 'aynı' kavramı üzerinden şekillenebilir:

"Esasında Aynı, olan (farklılıkların sonsuz çokluğu) değil, olacak olan'dır. Aynı'nın ancak başka bir şeyle birlikte ortaya çıktığını söylemiş ve bu şeye bir ad vermiştim: Hakikat. Farklılıklara karşı kayıtsız olan tek şey, bir hakikattir... Bir hakikat herkes için aynıdır...Aslında tek bir Özne yoktur, ne kadar hakikat varsa o kadar özne, ne kadar hakikat usulü varsa o kadar öznellik tipi vardır... Felsefe, zamanın tekil hakikatleri tarafından ifade edilen farklı öznellik tiplerinin bir arada var olabileceği bir düşünce alanı inşa etmeye çabalar. Ama bu bir arada varoluş bir birleşme değildir - bu yüzden de bir Etik'ten bahsetmek imkansızdır" ( Badiou, 2016, s. 4041).

Genel olarak etik diye bir şey yoktur. Sadece bir şeyin etiği vardır. Tekil bir olay, bu olayın ilkelerine sadakat tekil bir hakikat ortaya çıkarır. Ancak bu tekillik, olaya sadık olan öznelerin tamamı üzerinde tümel bir etik inşa eder. Badiou'nun etik felsefesi; pozitivist evrenselciliğin ve radikal nihilizmin hakikat kavrayışına aynı anda cevap verir bir niteliğe bürünmektedir.

Badiou hakikatin bütüncül ve kayıtsız şartsız iktidarının dayatılma gayretini, kötülügü̈n üç biçiminden biri felaket olarak adlandırır. ${ }^{4}$ Hakikatin öznesi devam edebilmek için, mutlak, nihai bir hakikat düzeni dayatma ayartısına düşmemelidir. Badiou'ya göre pozitivizm, Stalinizm, Jakobenizm gibi örnekler hakikati bütüncül hale getirip dayatmaya çalışan, yani hakikatin olaysal tikelliğinden sapan tarihsel örneklerdir (Badiou, 2016, s.89).

\footnotetext{
${ }^{4}$ Diğer iki kötülük örneği taklit (sahte bir olayın terör saçan takipçisi olmak) ve ihanettir (kendi çıkarı uğruna bir hakikatten vazgeçmek). Badiou kötülük biçimi olarak taklit için Nazizim örneğini uzun uzun ele alır. Sahte olay olarak tarif eder. Yanlış bir adlandırma 'her sahici olayın evrensel hitap alanıyla, belli bir halkın, cemaatin ya da yerin tözel doluluğu içine yerleşmiş hitap alanıyla karıştırılmasıdır.' Ari ırkı ya da Alman ulusunu evrenselleştirmeye çalışarak bir hakikat dayatmasına girmeleri, bu anlamda gerçek bir olayı taklit etmeleri (Badiou nasyonal sosyalistlerin Rus sosyalistlerin terminolojisini taklit etmesini örnek gösterir) ve öznelerin bu taklide kanarak terör sergilemeleri; etik felsefenin savurması gereken kötülük biçiminin tarihsel referansıdır. Etik bu kötülük biçimleri karşısında 'devam et' buyruğu altında feraset (taklitlere kanma!), cesaret (vazgeçme!) ve itidal (bütünlük aşırılığına kapılma!) araçlarını birleştirir. 'Hakikatler etiği ne dünyayı bir Yasa'nın soyut hakimiyetine tabi tutmayı, ne de dıssal radikal bir kötüye karşı mücadele etmeyi amaçlar. Tam tersine, hakikatlere gösterdiği sadakat yoluyla, Kötü'yü - tam da bu hakikatlerin dublörü ya da karanlık yüzü olarak gördüğü Kötü'yü- savuşturmaya çabalar.' (Badiou, 2016, s.92)
} 
Kötülük sorunu hakikatten sapma olarak ele alındığında, iyi ve kötü arasındaki 'etik ideolojinin' göstermeye çalıştığı mantıksal ilişki tersine çevrilmektedir. Badiou'nun etik ideoloji olarak adlandırdığı liberal-hümanist bakış açısı önce önsel bir kötü (totalitarizm, şiddet, 1stırap) varsayımı yapar ve ardından savunmacı karakterde bir etik, negatif özgürlüklere ve insan haklarına saygı dayatılır. Burada etik tacizkar müdahalelere karşı korunma anlamına gelir. Bu da statükonun düşünsel olarak olumlanmasıyla aynı kapıya çıar (Hallward, 2016). Kötülük sorununu hakikatin sapması olarak değerlendirildiğinde, hem savunmacı bir 'iyi' anlayışın terkedilmesi ve böylelikle toplumsal yeniden inşayı merkeze alan bir özne tanımlaması yapılmış oluyor çünkü agresif bir iyi, dayatmacı olmayan ama 'çokluklara' dayalı bir hakikat, toplumsal kurumları eşitlikçi bir zeminde yeniden inşayı gerekli kılar. Hem de hakikati perspektife indirgeyen ve böylece her türlü yıkıcı olayı da meşrulaştırabilecek post modern felsefenin hakikat tasavvuru ortadan kaldırılıyor. Hakikatin bir sürece bağlanması ve en önemlisi onu ancak taşıyıcısı özneyle ortaya çıkan bir olayla ilişkilendirilmesi; pozitivist geleneğin hakikati özneye dışsallaştıran, mutlak bir töz olarak gören gerici perspektifi de aşıyor.

Badiou'ya göre; siyasetin kolektif öznesi, kimliklere kayıtsız bir türsel çokluk inşası olmalıdır'(Türk, 2013, s287). Badiou, sonsuz çeşitlilikteki kimliklerden bir normun türetilemeyeceğini göstermeye çalışmaktadır. Evrensel bağlamda inşa edilecek olan, türsel bir çokluğun yani bir hakikat sürecinin ve onun öznesinin niteliğidir. Badiou' ya göre 'bir hakikatin öznesinin oluşumuna girmek ancak başınıza gelen bir şey olabilir' (Badiou, 2016, s.70). Bu bakış açısı hakikatin; sadece (kolektif) öznenin iradesiyle inşa edilemeyeceğini, aynı zamanda ilgili özneyi de içeren konjonktürel etkilere açık olduğunu göstermektedir. Hakikatler etiği, öznenin 'başına' gelen bu hakikat sürecinde devreye girmektedir. Hakikat sürecini devam ettirmenin pratik ilkelerini betimlemektedir.

Badiou'nun betimlediği hakikat usulleri, "durumun sadece en çıar gözetmeyen, en evrensel (en anonim) malzemelerinin ait olduğu 'türsel küme' oluştururlar:

Badiou'nün hakikat usullerini, dört ama sadece dört hakikat alanı arasında sıkı sıkıya paylaştırılmalarıyla dengelenir (bu alanların her biri felsefenin dört koşulu ya da türsel usulünden birini tanımlar). Aşk, sanat, bilim ve siyaset. Niye özellikle bu dördü? Çünkü bunlar bireysel ya da 
kolektif biçimleriyle öznenin olası kertelerine karşılık gelirler. Aşk, açıkça, sadece ilgili bireyleri etkiler. Siyaset, tersine, sadece kolektif boyutla, kesinlikle türsel bir eşitliğin olumlanmasıyla ilgilidir. 'Karma durumlarda' bireysel bir 'vasitasi' ama kolektif bir etkisi olan durumlarda ise sanat ve bilim, salt kabul gören bilgileri aktarmanın ötesinde katıksız bir icat ya da keşif gerçekleştirdikleri derecede türsel olma özelliği kazanırlar" (Hallward, 2016, s.140).

Badiou'nun projesinin amacı, özneler arasındaki farklılıkları bir hakikate 'sadık' kalarak ortadan kaldırmaya çalışmaktır. Örneğin bir hakikat olarak aşk olayının özneleri, toplumsal cinsiyet kimlikleri üzerinden farklılaşmış özneler olarak görülmeyecektir. Kendilerini ‘sadece o geçici karşılaşmış olma olayına duyulan sadakat içinde kök salmış olan aşık özneler olarak görmelerini' sağlayacaktır (Badiou, 2016, s. 73).

Konukseverlik etiği bağlamindan değerlendirdiğimizde hakikate sadakat, ev sahibi ve misafir özneler açısından aralarındaki eşitsiz ilişkinin ortadan kalktığı yeni bir durumu ortaya çıkartmaktadır. Mültecileri - bu söylemi dahi terk ederek- bulunduğu mekanların ortak kurucuları olarak değerlendirip karşılama pratiklerini bu çizgide sergileyen özneler, Badiou'nun 'durum' olarak tarif ettiği egemen hakikate karşı yeni bir hakikat inşa etmektedirler. Böylece mülteciliği hukuksal bir kimlik mücadelesine indirgemek yerine, kimliklere kayıtsız türsel bir çokluğun parçası haline getirmenin zeminini oluşturmaktadırlar.

\section{Sonuç}

Derrida'nın konukseverlik etiği üzerine belirgin tartışmaları, 90'lı yılların başında Cezayir'in Fransa işgaline karşı yürüttüğü direniş mücadelesinin sonlarına doğru sertleşen savaş ve Doğu Avrupa'da sosyalist sistemin çökmesiyle beraber gerçekleşen mülteci hareketlerinin konjonktüründe ortaya çıkmıştır. Levinas'ın etik felsefesi üzerine bina ettiği konukseverlik - kendi felsefesine ve bu konjonktürün mantığı uygun olarak- bir toplumsal hakikat tasavvuru üzerinden şekillenmemiştir. Özne, koşulsuz konukseverlik gösteren özne olarak, etik sorumluluğunu ancak misafir öznenin taleplerine teslim olarak gerçekleştirebilmektedir. Bu tarz bir etik sorumluluğun, mültecilere yönelik konuksevmez kaygıları cesaretle sakinleşti- 
rebilecek bir felsefi zemin sunduğunun hakkını teslim etmek gerekir. Ancak sorunu anlık vuku bulabilecek bir etik karşılama olayından çıkartıp, sürdürülebilir ortak yaşamı inşa etme bağlamında ele aldığımızda konukseverlik etiğinin sınırları belirgin hale gelmektedir.

Bugün güncel olarak ilgilendiğimiz mültecilik sorunsall, hukuksal bir kimlik mücadelesine sıkıştırıldıkça 'ev sahibi özneden' sürekli olarak başka, farklı ve en nihayetinde 'öteki' bir özne alanına hapsedilmektedir. Derrida'yı takip ederek, mültecilik sorunsalının çözümünde hukuk mücadelesi zeminini terk ederek etik bir ilişki zeminini inşa etmek gerektiğini belirtmek gerekir. Fakat konukseverlik etiğini politik bir hakikatin inşasıyla beraber işe koymadıkça, 'ev sahibi-misafir' ikiliğini -güncel olarak mültecilik sorunsalını- ortadan kaldırabilecek bir pratik zemini yakalayabilmek mümkün olmayacaktır.

Öznelerin sadakatle bağlandıkları bir hakikat olayı; misafir ve ev sahibi özneler arasındaki farkı - hakikate dahil olan özneler açısından- kayıtsız hale getirebilecek, farka kayıtsız kalan aynı etrafında ortak bir yaşamı inşa etmenin önünü açabilecektir. Koşulsuz konukseverliğin etik sorumluluğu olarak vazgeçme edimi ya da koşulsuz kabul, 'ev sahibi iken misafir olabilmek' cesareti, mültecilerin eşit yurttaşlar olarak dahil edileceği hakikat olayının zorunluluk ilişkisi bir ilk adım olarak düşünülmelidir. Koşulsuz kabul, radikal bir etik karardır ve ancak bu karar sayesinde özne onu hareketsiz kılan kaygı zincirlerini kırabilir. Fakat süreklilik ifade eden özneler arası bir etik ilişki için, vazgeçme veya koşulsuz kabul gibi radikal bir kararın yetmeyeceği de aşikardır. Hakikat olayının kendine içkin gelecek iddiası, özneleri sürekli olarak olay üzerinden müzakereye muhatap tutan yaratıcı potansiyeli ve en nihayetinde ona dahil olan özneler arasında yarattı̆̆ denklik mantığı, konukseverlik etiğinin güncel mültecilik krizi karşısındaki pratik sınırlılı̆̆ına çözüm getirmektedir. Bu çerçevede etik sorumluluk, birincisiyle tam ters istikamette ikinci bir edimi buyruk etmektedir. Ayrıcalıklarından vazgeçen ve gelen misafiri koşulsuz kabul eden özneler, farklılıklara kayıtsız bir hakikat olayında ssrar etmelidir. Israr edimi, vazgeçme ediminin aksine süreklilik ifade eden bir anlama sahiptir. Bu manada anlık vuku bulabilecek süreksiz bir etik kararın tamamlayıcısı olma potansiyeli taşımaktadır. Böylece vazgeçme ve ısrar, ev sahibi öznenin misafirle ortak bir hakikat olayına iştirak etmenin etik sorumluluğu olarak birbirini tamamlayabilmektedir. 
Badiou'nun hakikatler etiği ve bu etiğin politik hakikat tahayyülü ile Derrida'nın konukseverlik etiğinin radikal önerileri, güncel olarak mültecilik krizinin çözümüne dair özneleşmenin ilişkisel aşamalarının tamamlayıcı parçaları olarak okunabilir. Her iki etik felsefe arasında kurulacak böyle bir diyalektik ilişki, aynı zamanda mültecilik sorunsalına dair sosyal bilimsel çözümlemelerin kavramsal ve kuramsal çerçevesine de yaratıcı katkılar sunabilecektir. 
EXTENDED ABSTRACT

\section{Relational Analysis of Hospitality Ethic and The Ethic of Truths \\ * \\ Baran Yildırım \\ Anadolu University}

In this study, relational analysis of hospitality ethic has been discussed within two different context which have internal connections each other's. Two different contexts have been constructed two different intellectual method. First, determined relations of hospitality ethic has been described within abstraction method. Thus, the frame has been demonstrated how hospitality ethic come into social scientific analysis unit from its metaphysics context.

Abstraction and structural analyses which is the one of methods in realist paradigm has tools that those can convert the abstract phenomenon to concrete object. An abstraction, isolates in thought one-sided or partial aspect of an object and it is helpful to distinguish relations of different types. Therefore, the object which is constructed within relationality can be categorized as concrete.

One of the types of abstracted relations between contingency and necessity. It should be emphasized that the distinction between contingency and necessity is analytical rather than it is ontological. Those are internal relational that necessity can only be comprehended within context of contingency. The necessary relations are not unchangeable relations, unlike what naturalists claim, under every circumstances or space and time. The structure of necessary relations has been dominated by the contingency.

The contingent relations of hospitality ethic point to a specific consciousness which have been constructed in the hospitality experience. Accepting of stranger who can be even potential for danger requires renouncing all privileges which give the authority to 'host' front of 'guest'. For continuity of this kind of practice need a definite motivation which imply an egalitarian consciousness. Otherwise, holding privileges have been internalized for essential properties and therefore hospitality can be 
possible only within conditional form that guest must accept host's mastery.

The necessary relations of hospitality ethic have been tackled within motivations of the subject(host) who try to show unconditional hospitality that these motivations have been universalized as injustice to refugee or guest. Hence, we should argue that the motivations of being participate in unconditional hospitality may not contain the certain or common thought but practice itself and the space which is pure hospitality have occurred should necessitate an egalitarian logic.

Each two relations had been elaborated which based on philosophical debate of the subject and truth. This theoretical framework, at the same time, have caused the second section of this study.

In the second section; hospitality ethic and truth of ethic has been synthesized based on truth. This synthesis has been obtained through investigations which revealing to limitations of real politic of unconditional accept. The debates on philosophy of hospitality ethic which ground on Derrida's studies has been reread with criticism which had been framed by Badiou regarding the ethic of truth. Following the Badiou, ethic should be discussed within the truth which can be indifferent to diversity. So, there is no need to distinguish between host and guest that is one of the most significant ground for taking place of unconditional accept.

The critical reconstruction of hospitality ethic has been furthered adhere to relations of its which disclosure with abstraction method. These relations -contingent and necessary- have been interpreted in the field of truth which is theorized in the context of ethic by Badiou. Contingent relations have been analyzed within consciousness which is constructed in the event of truth while necessary relations have been discussed in the subjectivity context. Subjectivity is motivated by the process which transition from the 'anxiety' to the 'courage' for Badiou's theory. Courage which take a risk of being guest while you are host is deployed as a necessary component of the hospitality ethic. The categories of the abstracted relations of hospitality ethics have been illustrated within concepts which is argued from Badiou's studies for ethic of truth. Therefore, there've been avoided that the synthesis of two contrary ethic philosophy could have been remained with eclectically. 
The practical context of this study is current refugee crisis. The limits and possibilities of ethic philosophy in the reel politics which it can comprehend an answer of this crisis has been discussed to extend within the context of political subject which can solve refugee crisis. And thus, hospitality has not embraced only in the context of ethic but it has been also evaluated in the philosophy of subjectivity.

Forced migration and its social effects which occur in the recent years necessitate that we should rethink about concept of hospitality in social sciences. Concept of hospitality as a unit of social scientific analysis will reveal the relation of ethic and real politic. By this way, hospitality ethic can be tackled as a political act which can give theoretical proposition for solution of current refugee issue.

\section{Kaynakça / References}

Badiou, A., (2009). Theory of the subject. New York: Bloomsbury Academic.

Badiou, A., (2016). Etik, kötülük kavrayışı üzerine bir deneme. Çev: Tuncay Birkan. İstanbul: Metis Yayınları.

Baker, G., (2013). Hospitality and world politics. New York: Palgrave Macmillan.

Brotherton, B. ve Wood, R. C. (2007). 'Key Themes in hospitality management', R. C. Wood and B. Brotherton (eds), The Sage Handbook of Hospitality Management içinde, London: Sage, s. 35-61.

Bhaskar, R., (2013). Natüralizmin olanaklılığı: Çağdaş insan bilimlerinin felsefi bir eleştirisi, Çev: Vefa Saygın Öğütle, Ankara: Pratika Yayınları.

Bhaskar, R., (2015). Gerçekliği geri kazanmak: Çağdaş felsefeye eleştirel bir giriş, Ankara: Notabene Yayınları.

Derrida, J., (1999a). Differance, çev. Önay Sezer, Toplum ve Bilim Derrida Özel Sayısı İçinde, İstanbul.

Derrida, J., (1999b). Konuksev(-er/-mez-)lik, Çev. Ferda Keskin, Önay Sözer, Pera Peras Poros: Jack Derrida ile birlikte disiplinlerarası çalışma'nın içinde, İstanbul: Yapı Kredi Yayınları.

Derrida, J., (1999c). Adieu to Emmnuel Levinas. Standford California: Standfort University Press.

Derrida, J., (2000). Of hospitality. Standford California: Standfort University Press.

Diken, B.,(2013). İsyan, devrim, eleştiri- toplum paradoksu, Metis Yayınları, İstanbul 
Direk Z., (2003). Sunuş, sonsuza tanıklık içinde. İstanbul: Metis Yayınları, s.741.

Foucault, M., (2014). Özne ve iktidar, çev: Ferda Keskin, İstanbul: Ayrıntı Yayinlar1.

Gültekin, A. C., ( 2014). Bağışlanan konukseverlik ve konuksever bağışlama: Derrida felsefesinde etik ve politika ilişkisi. Felsefe ve Sosyal Bilimler Dergisi, 17, 13-34

Germann M. J., ve Gibson, S. (2007). Mobilizing hospitality: The ethics of social relations in a mobile World. Aldershot: Ashgate.

Hallward, P. (2013). Söyleşi ve sonsöz, alan badiou etik: kötülük kavrayışı üzerine bir deneme içinde (s.137). İstanbul: Metis Yayınları.

Kant, I., (1960). Ebedi barış üzerine felsefi denemeler, Çev: Yavuz Abadan ve Seha Meray, Ankara: Ajans Türk Matbaası

Kiravva, V., (2014). Politicizing hospitality: The emergency food assistance landscape in thessaloniki, Hospitality and Society içinde, s.249-261

Levinas, E., (2003). Biriciklik üzerine, sonsuza tanıklık içinde, İstanbul: Metis Yayinlar1, s.191-199

Naas, M., (2006). Jacques Derrida ve konukseverlik sorusu, Cogito, s. 237

Sayer, A., (1992). Method in social science: a realist approach (Çev: Abdülkerim Sönmez), New York and London: Routledge

Stocker, B., (2006). Derrida etiğinde çelişki, aşkınlık ve öznellik, Cogito, 47-48, 335-347

Selwyn, T. (2000). 'An anthropolgy of hospitality', C. Lashey and A. Morrison, In Search of Hospitality: Theoretical PErspectives and Debates, Oxford: Butterworth-Heinemann, (s. 18-37)

Telfer, E.,(2000). 'The Philosophy of hospitableness', C. Lashley and A. Morrison (eds), In Search of Hospitality: Theoretical Perspectives and Debates içinde, Oxford: Butterworth-Heinemann, s. 38-55.

Thompson, E. P., (2004). İngiliz işçi sınıfının oluşumu, çev. Uygur Kocabaşoğlu, İstanbul: Birikim yayınları.

Türk, D., (2013). Öteki, düşman, olay: Levinas, Schmitt ve Badiou'da etik ve siyaset, İstanbul: Metis Yayınları.

Vanderberghe, F., (2012). Pierre Bourdieu'nun üretken yapısalcılı̆̆ının epistemolojik bir analizi, Güney Çeğin ve Emrah Göker (Ed.) Tözcülüğ̈̈̈n Tasfiyesi içinde (s. 385), Ankara: Notabene Yayınları

Yeğenoğlu, M., (2012). Avrupa'da islam, göçmenlik ve konukseverlik. İstanbul: İstanbul Bilgi Üniversitesi Yayınları 
Kaynakça Bilgisi / Citation Information

Yıldırım, B. (2021). Konukseverlik etiğinin ilişkisel analizi ve hakikatler etiği. OPUS-Uluslararası Toplum Araştırmaları Dergisi, 17(39), 929957. DOI: $10.26466 /$ opus.845830. 